\title{
KONTROVERSI PARA MUFASIR DI SEPUTAR TAFSÎR BI AL-ILMI
}

\author{
Oleh: Sulthan Syahril ${ }^{*}$
}

\section{Abstract}

The following article examines the view of the mufasir (especially Imam Jamaluddin alSuyuti, Sheikh Tantawi Jauhari, al-Zahabi and Mahmud Syaltut) tegarding the existence of the tafsir bi al-ilmi and their arguments, how do four mufasir attitudes and respond towards the verses kauniyah in al-Qur'an? whether these verses are understood in the scientific level, or understood as Hidayah? Given that al-Qur'an is the "Book of Hidayah". The method that used in this research is descriptive-analytical methods and comparative. The implementation of those three methods have been conducted together. The results of the research revealed that the controversy surrounding the mufasir concerning tafsir bi al-ilmi appears due to the desire of each mufasir to show the correlation between science and the Qur'an as the boly book of all time and apply modern science that can correct used as a means to understand the greatness of God shown through His verses.

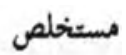

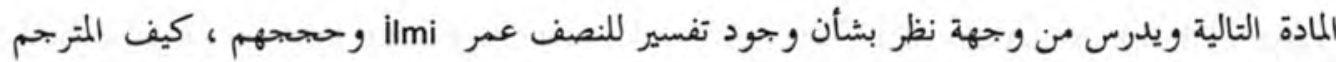

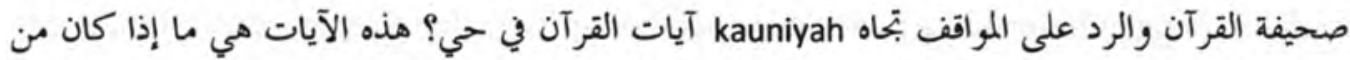

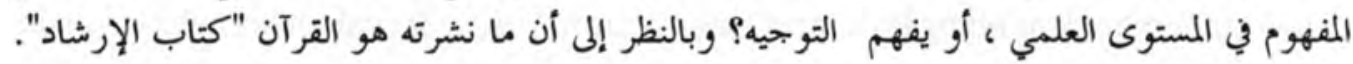

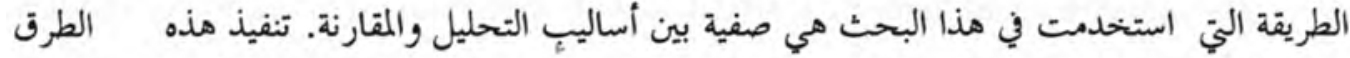

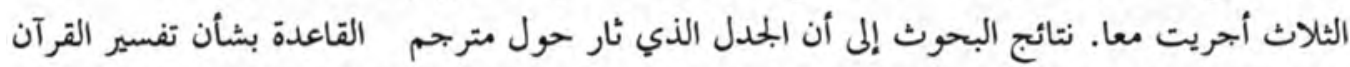

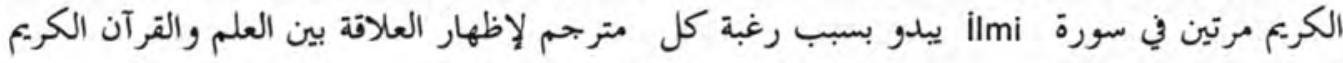

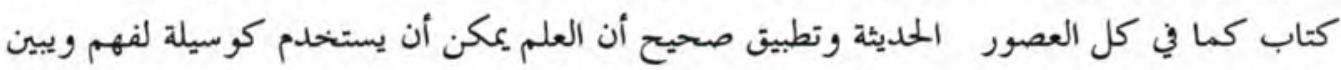
عظمة الله من خحلال الآيات

Keywords: al-Quran, Tafsîr bi al-Imi, Sains Modern dan Teknologi

Dosen IAIN Raden Intan Lampung. Email: sulthansyahril@yahoo.com. 


\section{A. Pendahuluan}

Pada dasarnya setiap kitab suci sarat akan ambivalensi. Di satu pihak berakar pada kurun waktu tertentu (sifat duniawr) dan di lain pihak seakan-akan menawarkan hal-hal yang bersifat transendental serta nilai-nilai permanen kepada umat manusia (aspek ukhrawi), kendatipun dalam konteks ini masih menjadi persoalan yang kontroversial di kalangan para mufasir. Sebagai konsekuensi dari pertentangan ini bagi para mufasir yang tidak ingin dicap sebagai kelompok yang ketinggalan zaman menyikapinya dengan upaya-upaya akademik yang membuktikan bahwa kitab suci (Al-Qur'an) dapat memenuhi kebutuhan dan tuntutan masa kini, baik secara material maupun spritual.

Munculnya berbagai kontroversi di kalangan mufasir ini sesungguhnya dapat dipahami, sebab di satu sisi Nabi Muhammad SAW sebagai pemegang otoritas pertama terhadap penafsiran Al-Qur'an telah memberikan penjelasan-penjelasan terhadap ayat-ayat Al-Qur'an, walaupun penjelasan tersebut tidak mencakup keseluruhan dari ayat-ayat yang terdapat di dalam Al-Qur'an. Akan tetapi di sisi lain spirit dan sinyalsinyal yang diberikan Al-Qur'an dalam bentuk anjuran untuk melakukan perenungan dan memikirkan terhadap ayat-ayat Al-Qur'an memberikan indikasi bahwa Al-Qur'an harus dipahami dan senantiasa harus berdialog dengan manusia, kapan dan di manapun mereka berada.

Eksistensi Al-Qur'an sebagai kitab petunjuk menuntut kepada manusia untuk selalu mengadakan kajian dan perenungan terhadap makna dan pengertian AlQur'an yang telah dikemukakan oleh para mufasir karena situasi dan kondisi yang berbeda, terlebih dengan banyaknya penemuan-penemuan sains dan teknologi modern, tentunya ikut memberikan kontribusi untuk memahami Al-Qur'an dalam konteks kekinian. Persoalan yang muncul kemudian adalah sejauh mana sains dan teknologi modern dapat dijadikan referensi untuk menafsirkan Al-Qur'an. Dalam konteks ini muncul sikap pro dan kontra di kalangan mufasir di dalam merespons penafsiran yang menggunakan pendekatan ilmiah (tafsîr bi al-ilmi).

Sikap pro dan kontra ini sesungguhnya muncul dikarenakan Al-Qur'an merupakan kitab suci yang bernilai absolut, sementara ilmu pengetahuan (sains) lebih bernilai relatif. Bagaimana menerapkan sesuatu yang bernilai relatif dapat dianggap sebagai pandangan Al-Qur'an?

Mengkaji tentang kontroversi para mufasir di seputar tafsîr bi al-ilmi dalam penelitian ini tentu saja sangat beralasan, karena kenyataan di dalam Al-Qur'an terdapat kata-kata atau ungkapan-ungkapan yang memiliki makna ganda. Hal ini 
memberikan indikasi bahwa peluang munculnya penafsiran yang ingin menyesuaikan semangat Al-Qur'an dengan perkembangan zaman sangat besar dan ini membuktikan bahwa Al-Qur'an mampu menjawab tantangan kontemporer baik secara material maupun spiritual. ${ }^{1}$ Setidak-tidaknya ada beberapa alasan akademik yang mendorong penulis untuk melakukan penelitian ini:

1. Era sains dan teknologi yang ditandai dengan banyaknya penemuanpenemuan ilmiah memberi peluang munculnya tafsîr bi al-ilmi.

2. Munculnya pola penafsiran dengan pendekatan ilmiah (tafsîr bi al-ilmi) pada mulanya dilatarbelakangi oleh kemunduran umat Islam, sehingga hal ini memberi kesan bahwa tafsîr bi al-ilmi dimaksudkan sebagai kompensasi terhadap inferiority complex (perasaaan rendah diri) yang melanda umat Islam.

3. Kajian tentang kontroversi para mufasir di seputar tafsîr bi al-ilmi ini cukup menarik untuk dieksplorasi secara maksimal.

Secara spiritual kajian dalam penelitian ini diarahkan pada upaya untuk menemukan jawaban-jawaban dari beberapa pertanyaan yang muncul dalam rumusan masalah sebagai berikut:

1. Bagaimana pandangan para mufasir (khususnya Imam Jamaluddin alSuyuti, Syaikh Tantawi Jauhari, al-Zahabi dan Mahmud Syaltut) terhadap eksistensi tafsîr bi al-ilmi dan apa argumentasi yang mereka kemukakan?

2. Bagaimana sikap keempat mufasir tersebut di dalam merespon ayat-ayat kauniyah yang ada di dalam Al-Qur'an? Apakah ayat-ayat tersebut dipahami dalam tataran ilmiah atau dipahami sebagai hidayah, mengingat bahwa Al-Qur'an merupakan "Kitab Hidayah".

\section{B. Tafsîr bi al-Ilmi}

Term tafsîr bi al-ilmi terdiri dari rangkaian dua kata yang mempunyai arti yang berbeda. Tafsîr berarti takwil, penjelasan, keterangan, komentar. ${ }^{2}$ Sedangkan ilmi atau ilmu memiliki pengertian berdasarkan ilmu pengetahuan. ${ }^{3}$ Lebih jauh

1 Taufik Adnan Amal, "Pembaharuan Penafsiran al-Qur'an Di Indo-Pakistan”, dalam Ulumul Qur'an, Vol. III., 2, 1992, hal. 62. hal. 583 .

2 Luwica Ma'luf, al-Munjîd fî al-Lughah wa al-A'lam, Cet. 30, (Beirut: Dar al-Masyriq, 1998),

3 Ahmad Warson Munawir, al-Munawwir Kamus Arab-Indonesia, (Yogyakarta: Pustaka Progressif, 1999), hal. 1037. 
dapat dijelaskan bahwa ilmi berarti pula ilmu alam yang mempelajari apa yang ada di alam, baik dari segi materi, unsur-unsur, maupun fakta-fakta alam yang memiliki karakter benda, tersusun oleh hukum-hukum tertentu, seperti kimia, fisika, mekanika dan lain sebagainya. Termasuk dalam kategori ini adalah ilmu kedokteran, eksakta, ilmu falak dan ilmu fakta-fakta alam lainnya. ${ }^{4}$ Sementara Quraish Shihab menjelaskan bahwa ilmu dalam konteks ini adalah hanya terbatas pada pengertian sains yang meliputi pengungkapan sunatullâh tentang alam raya (hukum-hukum alam) dan perumusan hipotesis-hipotesis yang memungkinkan seseorang dapat mempersaksikan peristiwa-peristiwa alamiah dalam kondisi tertentu. ${ }^{5}$

Al-Zahabi lebih jauh menjelaskan bahwa tafsîr bi al-ilmi adalah tafsîr yang menerapkan beberapa istilah ilmiah terhadap teks-teks Al-Qur'an dan berusaha untuk mengekspresikan bermacam-macam ilmu pengetahuan (termasuk non sains) dan ide-ide filosofis yang terkandung di dalamnya. ${ }^{6}$ Pengertian ini menunjukkan bahwa tafsîr bi al-ilmi adalah penafsiran yang ditempuh oleh para mufasir dengan cara menghubungkan ayat-ayat Al-Qur'an dengan teori-teori dan istilah-istilah ilmiah, serta berusaha semaksimal mungkin untuk mengekspresikan berbagai persoalan ilmu pengetahuan dan ide-ide filosofis yang terkandung di dalamnya. Sementara Taufik Adnan Amal mengatakan bahwa tafsîr bi al-ilmi adalah penafsiran yang berusaha untuk membuktikan bahwa sains-sains modern tidak bertentangan dengan Al-Qur'an dan bahkan sains-sains modern tersebut dapat diproduksi dari Al-Qur'an. ${ }^{7}$

Dari berbagai definisi di atas, dapat disimpulkan: pertama, dalam tafsîr bi al-ilmi para mufasir berusaha mengorelasikan antara Al-Qur'an dengan teori-teori ilmiah sebagai bahan penafsiran, term ini tampak pada dua definisi di atas. Kedua, para mufasir berusaha untuk mengekspresikan berbagai disiplin keilmuan (termasuk ilmu sosial) dan ide-ide filosofis yang dikandung suatu ayat. Ketiga, yang menjadi objek dalam kajian tafsîr bi al-ilmi adalah ayat-ayat yang berkenaan dengan istilahistilah ilmiah atau lebih populer dengan sebutan ayat-ayat Kauniyah. Keempat, asumsi dari tafsîr bi al-ilmi, bahwa antara Al-Qur'an dan ilmu pengetahuan tidak terdapat pertentangan sebagaimana tampak pada definisi ketiga.

4 Fadh Abd. Al-Rahman, Ittijahât al-Tafsîr fî al-Qarn al-Rabi' 'Asyar, (Riyad: Mamlakah alArabiyah al-Sa'udiyah, 1986), hal. 546.

M. Quraish Shihab, Membumikan al-Qur'an, (Bandung: Mizan, 1992), hal. 63.

6 Al-Zahabi, al-Tafsîr wa al-Mufassirûn, II, (Beirut: Dar al-Fikr, 1976), hal. 474.

7 Taufik Adnal Amal, "Pembaharuan Penafsiran Di Indo-Pakistan"..., hal. 62. 
Dari latar belakang historis dapat diketahui bahwa konseptualisasi tafsir bi alilmi muncul pada awal revolusi pemikiran yang terjadi di Eropa pada abad ke-19 Masehi, kemudian diikuti oleh revolusi industri yang ditandai oleh munculnya berbagai kreasi dan penemuan baru, sehingga membuat Eropa lebih unggul dalam bidang sains dan teknologi dibandingkan dunia Islam. Hal ini membuat perasaan rendah diri (inferiority complex) di kalangan sebagian besar kaum muslimin. Sebagai implikasinya, terjadi kompensasi di kalangan kaum muslimin dengan cara mengenang kembali kejayaan Islam masa lalu dengan berbagai peninggalan yang monumental (adab al-fakhri wa al-tamjîd), terutama yang terjadi di abad-abad pertengahan. ${ }^{8}$ Kondisi seperti ini menyadarkan sebagian ahli tafsîr untuk merespons berbagai kemajuan yang dicapai Barat. Mereka berusaha menggugah semangat dan motivasi umat Islam dengan mengadakan atau melakukan reformasi penafsiran terhadap ayat-ayat Al-Qur'an.

Setidak-tidaknya ada faktor yang melatarbelakangi kehadiran tafsîr bi al-ilmi, yaitu: faktor internal, yakni keyakinan bahwa Al-Qur'an sebagai pedoman hidup memuat seluruh aspek kehidupan manusia; sebagian ayat-ayat Al-Qur'an membahas tentang persoalan jagad raya dan fenomena-fenomenanya, yang lazim disebut sebagai ayat-ayat kauniyah. Pada umumnya ayat-ayat kauniyah sering diakhiri dengan perintah untuk berpikir, menganalisis, memperhatikan dan lain sebagainya. Hal ini oleh sebagian mufasir dipandang sebagai indikasi perlunya penafsiran baru terhadap ayat-ayat tersebut dengan menggunakan pendekatan ilmiah (tafsîr bi al-ilmi).

Munculnya tafsîr bi al-ilmi tentu saja memiliki dampak terhadap makna AlQur'an. Karena ayat Al-Qur'an jika ditafsîr kan dengan menggunakan pendekatan ilmiah penafsirannya akan senantiasa disesuaikan dengan teori-teori yang berkembang di dalam dunia ilmu pengetahuan, sementara teori-teori dalam ilmu pengetahuan akan mengalami dinamika dan perkembangan. Apa yang menjadi kebenaran pada waktu tertentu, boleh jadi tidak relevan lagi pada waktu yang lain, dikarenakan muncul teori baru yang lebih relevan. Sebagai contoh, teori bumi datar yang merupakan satu hukum aksioma pada suatu masa,tumbang dengan hadirnya teori bumi bulat yang berkembang kemudian. Teori ini mengatakan bahwa bumi itu lonjong seperti bentuk telur. Demikian pula dengan teori-teori yang datang kemudian.

8 M Quraish Shihab, Membumikan Al-Qur'an..., hal. 52. 


\section{Telaah dan Kerangka Pemikiran}

Dalam tradisi ilmiah, tidak sedikit para pakar yang secara spesifik menulis dan mencermati kajian yang berkaitan dengan tafsîr bi al-ilmi. Hal ini dibuktikan di dalam buku Hanafi Ahmad (tanpa tahun), dengan judul: al-Tafsîr al-Ilmi li al-Ayât al-Kauniyah, Makkah, Dar al-Ma'arif. Konklusi dari buku ini memaparkan hal yang sangat mendasar, antara lain:

Pertama, sebagian ayat-ayat Al-Qur'an ada yang mengkaji tentang penciptaan alam raya dan fenomenanya yang memotivasi manusia untuk berpikir serta merefleksikannya, sehingga mengarahkan manusia untuk mengenal Allah dalam arti yang sebenarnya dan membenarkan risalah-Nya, di samping memberi petunjuk kepada jalan yang benar.

Kedua, ayat-ayat tersebut ada juga yang menunjukkan sunnatullah, proses penciptaan makhluk dan pengaturannya, ada pula sebagian yang menjelaskan keragaman makhluk terkait dengan sifatnya, penciptaan dan karakteristiknya, namun ada pula makhluk yang tidak dijelaskan sifat-sifatnya. Ayat-ayat semacam ini dinamakan ayat-ayat kauniyah. Sisi kesamaan dengan penelitian ini adalah samasama mengkaji tentang interpretasi tafsîr bi al-ilmi secara konseptual. Sedangkan perbedaannya terletak pada fokus penelitian. Jika penelitian atau kajian Hanafi Ahmad terfokus pada upaya mentafsîr kan ayat-ayat kauniyah yang disesuaikan dengan kondisi pada waktu itu, maka kajian sekarang lebih berorientasi pada upaya mengungkap kontroversi para mufasir di seputar tafsîr bi al-ilmi dengan berbagai persoalannya.

Kajian selanjutnya dilakukan oleh Tantawi Jauhari (tanpa tahun), dalam bukunya al-jawâhir Fî Tafsîr Al-Qur'ân, Juz I, Cet. 2. Kesimpulan dari tulisannya memaparkan bahwa tafsir dengan corak ilmiah dimaksudkan agar umat Islam memiliki kesadaran penuh untuk menuntut ilmu pengetahuan dalam arti yang seluas-luasnya, yakni ilmu fisika, pertanian, matematika, pertambangan, ilmu ukur (geometri), ilmu falak dan ilmu pengetahuan modern lainnya.

Mengacu kepada persoalan yang menjadi fokus penelitian ini, maka setidaktidaknya ada dua aspek yang dijadikan kerangka pikir. Pertama, terkait dengan pandangan para mufasir (terutama Imam Jalaluddin al-Sayuti, Tantawi Jauhari, alZahabi, dan Mahmud Syaltut) terhadap eksistensi tafsîr bi al-ilmi dan argumentasi yang mereka kemukakan. Kedua, terkait dengan sikap keempat mufasir dalam merespons ayat-ayat kauniyah yang ada dalam Al-Qur'an. 
Visualisasi kerangka pikir di atas, dapat dilihat dalam skema berikut:

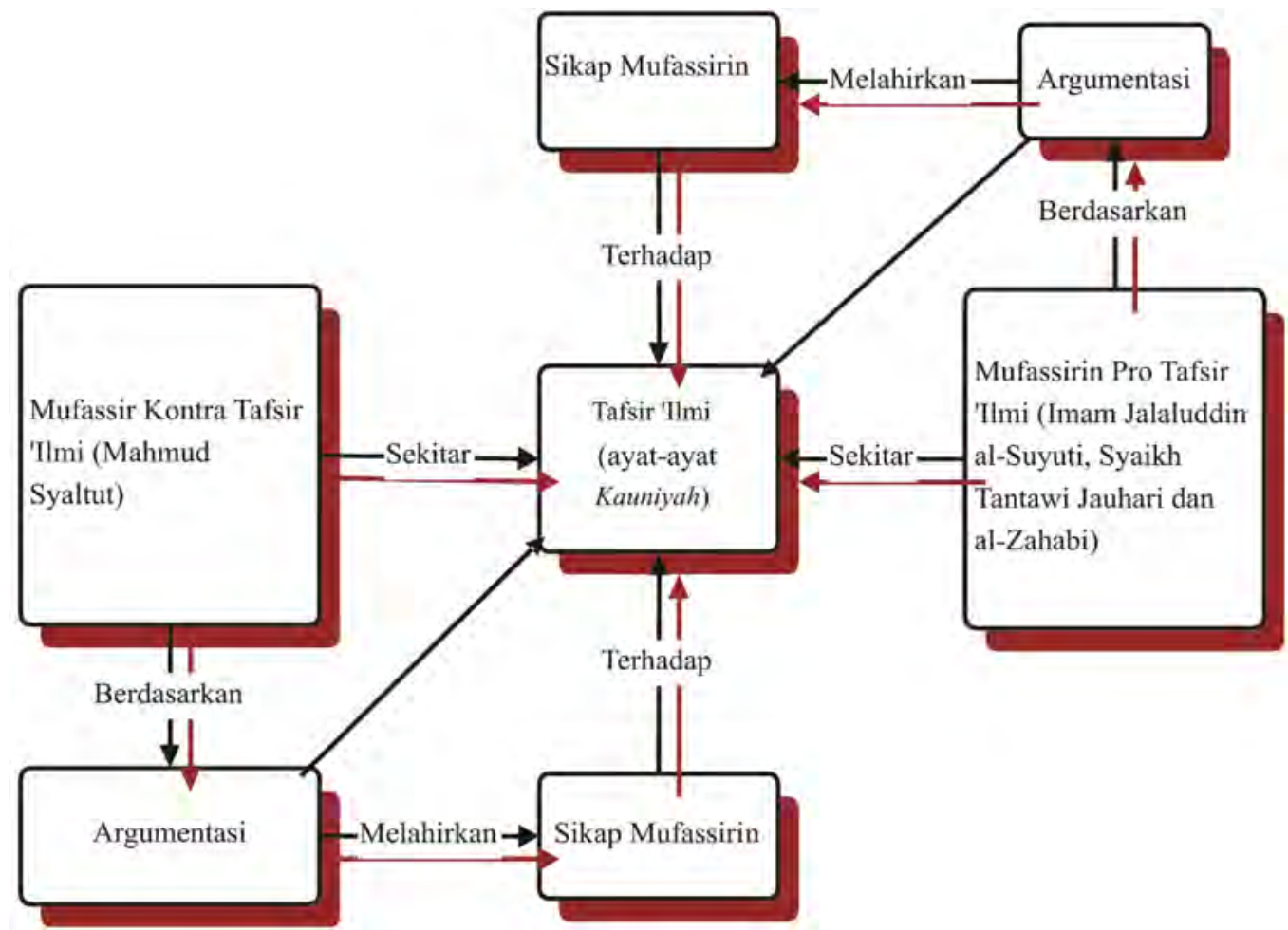

Kerangka pikir di atas memberikan gambaran, munculnya tafsîr bi al-ilmi melahirkan pro dan kontra di kalangan para mufasir, terutama di dalam menafsirkan ayat-ayat kauniyah. Masing-masing memiliki argumentasi ilmiah, sehingga melahirkan sikap-sikap tertentu. Para mufasir yang pro terhadap penafsiran ayat-ayat kauniyah menyambut dan mengekspresikan sikap positif, sementara kelompok yang kontra secara negatif, karena ayat-ayat Al-Qur'an pada dasarnya cukup diyakini, dan secara substansial kandungannya tidak pernah bertentangan dengan kebenaran apapun termasuk kebenaran ilmiah yang dapat diterima oleh akal pikiran yang logis.

\section{Metode Penelitian}

Metode yang digunakan dalam penelitian ini adalah metode deskriptif-analitik dan komparatif. Penerapan ketiga metode ini dilakukan secara akumulatif dan bersama-sama. Metode deskriptif dipergunakan dalam konteks pemaparan dan memberikan gambaran umum tentang persoalan-persoalan yang akan diteliti, 
kemudian dari data-data yang terkumpul dilakukan kajian-kajian dan interpretasi. Sedangkan metode analisis dipergunakan untuk melihat secara kritis berbagai persoalan yang melatarbelakangi masalah-masalah yang dikaji.

Penerapan metode komparatif adalah dalam konteks memahami perbedaan pendapat di kalangan mufasir, khususnya yang terkait dengan sikap dan respon masingmasing terhadap kehadiran tafsîr bi al-ilmi. Dalam kaitannya dengan prosedur pengolahan data, metode yang dipergunakan adalah content analysis, yaitu menganalisis validitas instrumen atau data yang hendak diukur, melalui proses tahapan pengolahan data, sehingga data tersebut siap diinterpretasikan dan disimpulkan.

\section{E. Hasil Penelitian dan Analisis}

Secara umum keempat mufasir yang telah disebutkan di atas, kecuali Mahmud Syaltut memandang positif atas kehadiran tafsîr bi al-ilmi, bahkan mereka menjadi pelopor dalam upaya menafsirkan Al-Qur'an melalui pendekatan ilmiah.

Al-Suyuti dalam kitabnya al-Itqân fì 'Ulùm Al-Qur'ân, al-Iklîl fî̀ Istimbât alTan₹̨il dan al-Mumtarikh al-Aqran fî I'jâzi Al-Qur'ân mengungkapkan secara luas berbagai argumentasi yang mendukung sikap serta pendapatnya bahwa semua ilmu yang berkembang hari ini sampai hari kiamat telah diungkap di dalam Al-Qur'an dan dapat dieksplorasi dari Al-Qur'an. Dan untuk memperkuat argumentasinya, alSuyuti mengutip beberapa ayat Al-Qur'an dan hadis.

Di antara ayat-ayat Al-Qur'an yang dikutipnya adalah surat al-An'am ayat 38, an-Nahl ayat 89 , sebagai berikut:

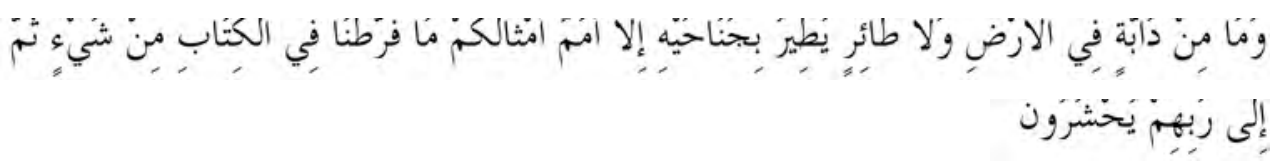

"Dan Tiadalah binatang-binatang yang ada di bumi dan burung-burung yang terbang dengan kedua sayapnya, melainkan umat (juga) seperti kamu. Tiadalah Kami alpakan sesuatupun dalam Al-Kitab, kemudian kepada Tuhanlah mereka dihimpunkan.” (Q.S al-An'am: 38)

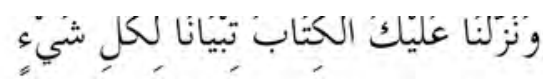

“.... dan Kami turunkan kepadamu al-kitab (Al-Qur'an) untuk menjelaskan segala sesuatu....” (Q.S. an-Nahl: 89) 
Sedangkan hadis Nabi yang dijadikan dasar bagi pendapat adalah hadis yang dikeluarkan oleh al-Turmuzi dan Hamzah al-Zayyat dari Mukhtar al-Ta'i dari ibn Akhi al-Harits al-A'war, sebagai berikut :

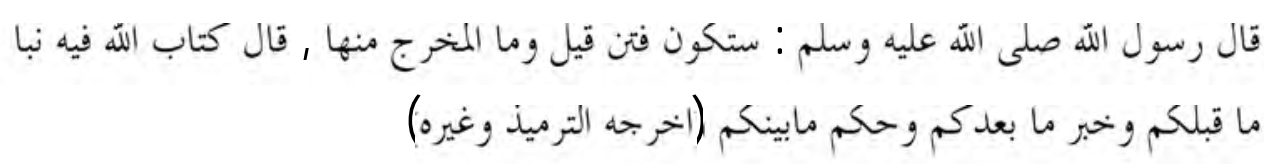

"Rasulullah SAW bersabda: "akan terjadi kejahatan-kejahatan", lalu beliau ditanya, "apa yang dapat menyelamatkan kita darinya ? Nabi menjawab: kalian dan berita-berita tentang apa yang akan terjadi setelah kalian, serta semua keputusan di antara kalian." 9

Disamping itu, al-Sayuti juga mengutip pendapat Ibn Mas'ud yang diriwayatkan oleh Sa'id Ibn Mansur dari Khuzaij Ibn Mu'awiyah, dari Ishak dari Murrah, sebagai berikut: ${ }^{10}$

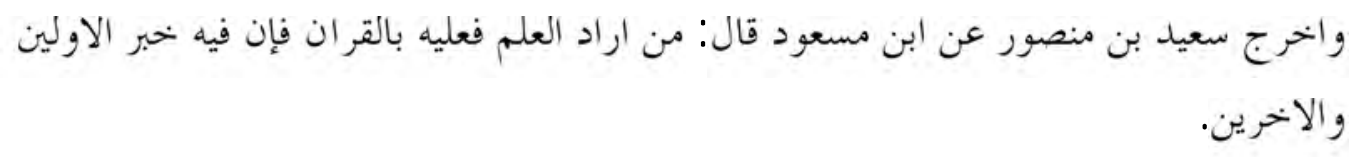

Dari beberapa ayat, hadis dan atsar di atas dapat disimpulkan bahwa al-Sayuti memahami kata al-Kitâb dengan Al-Qur'an, dan kata Syai'in pada surat an-Nahl ayat 89 dengan "segala sesuatu", termasuk di dalamnya ilmu pengetahuan.

Mufasir lain dari kalangan kontemporer yang dianggap sebagai pelopor tafsîr bi al-ilmi adalah Syaikh Tantawi Jauhari. Di dalam tafsir al-Jawâhir fi Tafsîr AlQur'ân, ia mengungkapkan berbagai macam ilmu pengetahuan, terutama ketika menafsirkan ayat-ayat kauniyah. Penafsirannya tidak hanya terbatas pada uraian dan penjelasan dalam bentuk kata-kata, tetapi ia juga mengkaji penafsiran dengan gambar-gambar, baik gambar hewan, tumbuh-tumbuhan maupun lainnya.

Al-Zahabi di dalam kitab al-Tafsîr wa al-Mufassirin menjelaskan bahwa metode yang dipergunakan oleh Tantawi Jauhari di dalam tafsîr annya adalah memberikan tafsir an-tafsir an secara lafdži dan kemudian dilanjutkan dengan kajian-kajian yang bersifat ilmiah yang lazim disebutnya sebagai latâif atau jawâhir. Pembahasan-

9 Al-Sayuti, al-Itqân fì 'Ulûm Al-Qur'ân, (Beirut:Dar al-Fikr, t.t), juz, 4, hal. 125-126. Lihat juga, al-Turmudzi, Sunan al-Turmudzi, (Semarang: Thoha Putra, t.t), juz 4, hal. 345-346.

10 Al-Sayuti, al-Iklîl fi Istimbât al-Tanžîl, (Beirut: Dar al-Tsaqafah al-Islamiyah, t.t), hal. 5. 
pembahasan tersebut menurut al-Zahabi merupakan akumulasi dari pendapat para pemikir Barat dan Timur zaman modern. ${ }^{11}$ Kajian-kajian yang bersifat keilmuan menurut al-Zahabi juga ditransfer oleh Tantawi Jauhari dari Injil Barnabas yang dianggap sebagai injil yang paling sahih, juga dari Plato dan Ikhwan al-Safa dalam risalahnya. Tantawi Jauhari juga menggunakan teori-teori ilmiah modern pada saat menafsirkan ayat-ayat Al-Qur'an, dimana teori-teori tersebut belum pernah ada di Arab pada masa sebelumnya. ${ }^{12}$

Dari uraian yang dikemukakan al-Zahabi di atas dapat diberikan beberapa contoh, misalnya, pada halaman 24 dari Tafsir al-Jawâhir fi Tafsîr Al-Qur'ân juz 2 diuraikan sedemikian jelas tentang perkembangan katak mulai dari telur sampai proses menjadi katak yang besar. Pada juz 3 halaman 102 juga diuraikan tentang ilmu-ilmu kimia, macam-macam atom, sifat-sifat atom dan daftar unsur-unsur dalam ilmu kimia. Di dalam juz yang sama pada halaman 141 dijelaskan betapa pentingnya ilmu-ilmu biologi, antropologi, pertambangan dan kedokteran.

Demikian pula dapat kita temui uraian tentang sejarah timbulnya pesawat udara dan perkembangan selanjutnya sebagaimana yang terdapat pada juz 8 halaman 97 dan sebagainya. Alasan yang mendorong Tantawi Jauhari menulis tafsîr dengan corak ilmiah, sebagaimana yang dikemukakan dalam muqaddimah tafsîr nya adalah agar umat Islam sadar untuk menuntut ilmu dalam pengertian yang seluas-luasnya, yakni ilmu fisika, ilmu pertanian, matematika, pertambangan, ilmu ukur, ilmu falak, dan ilmu pengetahuan modern lainnya. ${ }^{13}$ Menurut Tantawi, Al-Qur'an banyak mengandung ayat-ayat yang mendorong umat Isam untuk maju dalam berbagai ilmu pengetahuan. Bahkan menurut perhitungannya tidak kurang dari 750 ayat yang secara spesifik membicarakan tentang keajaiban alam, manfaat serta keunikannya atau dikenal dengan ayatayat kauniyah.

Berbeda dengan Tantawi Jauhari, Mahmud Syaltut (mantan Rektor Universitas al-Azhar Mesir) yang menolak kehadiran tafsîr bi al-ilmi. Di dalam muqaddimah tafsirnya ia mengemukakan berbagai corak tafsir yang berkembang sepanjang sejarahnya. Ada tafsir yang menitikberatkan uraiannya pada penggunaan kaidahkaidah gramatikal (nahwu), segi balaghah dan i'jâz, Al-Qur'ân. Bahkan sejalan dengan perkembangan ilmu pengetahuan dan teknologi modern, ada sebagian mufasir yang

\footnotetext{
11 Al-Zahabi, al-Tafsî̀ wa al-Mufassirûn..., hal. 508-509.

12 Ibid.

13 Ibid.
} 
cenderung menulis tafsir dengan corak ilmiah atau tafsîr bi al-ilmi. Dari beberapa corak penafsiran ini Syaltut memberi catatan penting yang sekaligus dapat dilihat sebagai sikapnya dalam menafsirkan Al-Qur'an.

Pertama, hendaknya seorang mufasir menghindarkan diri dari pentakwilan Al-Qur'an menurut pendirian berbagai aliran, karena hal ini menurut Syaltut akan menyebabkan pemaksaan penafsiran sesuai dengan para fuqaba', para mutakallimin, maupun ahli tasawuf yang cenderung fanatik terhadap kelompok masing-masing. Kedua, hendaknya menjauhkan diri dari upaya menafsirkan Al-Qur'an dengan menggunakan teori-teori ilmiah. ${ }^{14}$

Namun di sisi lain, perkembangan sains dan teknologi tidak sedikit memberikan andil dalam mengungkap berbagai kenyataan yang disinyalir di dalam Al-Qur'an melalui ayat-ayatnya. Berbagai penemuan ilmiah tersebut oleh sebagian mufasir dihubungkan dengan teks-teks yang terdapat di dalam Al-Qur'an. Sebagai contoh, ketika Al-Qur'an mengemukakan fenomena alam, seperti hujan, petir dan sebagainya, mereka mengklaim bahwa Al-Qur'an berbicara tentang kosmologi.

Demikian pula ketika Al-Qur'an menyebut matahari, bulan, bintang-bintang dan planet-planet, mereka mengatakan bahwa Al-Qur'an berbicara tentang astronomi dan lain sebagainya. Mereka menggunakan ayat 38 surat al-An'am sebagai landasan formal untuk memperkuat pendapat mereka. Berbagai pendapat di atas, ditolak oleh Mahmud Syaltut dengan menunjukkan sisi-sisi kesalahan yang dilakukan oleh para mufasir bi al-Ilmi ketika menafsirkan ayat-ayat kauniyah. Di antara contoh yang diangkat oleh Syaltut adalah penafsiran terhadap ayat 10-11 surat ad-Dukhaan, sebagai berikut:

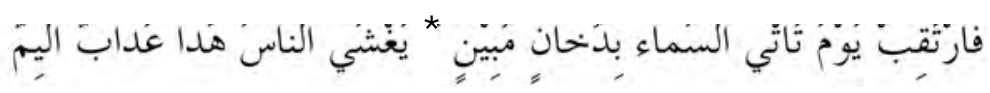

"Maka tunggulah hari ketika langit membawa kabut yang nyata, yang meliputi manusia. Inilah azab yang pedih." (Q.S Ad-Dukhaan 10-11).

Dalam konteks ini, mereka menafsirkan kata ad-Dukhân dengan gas beracun dan gas-gas pembunuh yang dihasilkan dari banyak macam alat pemusnah dan penghancur. Penafsiran semacam ini menurut Syaltut merupakan penafsiran yang keliru, karena mereka telah mengabaikan ayat berikutnya, yaitu ayat 12-14:

14 Mahmud Syaltut, Tafsîr Al-Qur'ân al-Karîm al-Ajzấ' al-Asyarah al- Ulâ, (Beirut: Dar al-Syuruq, 1974), hal. 9-10. 


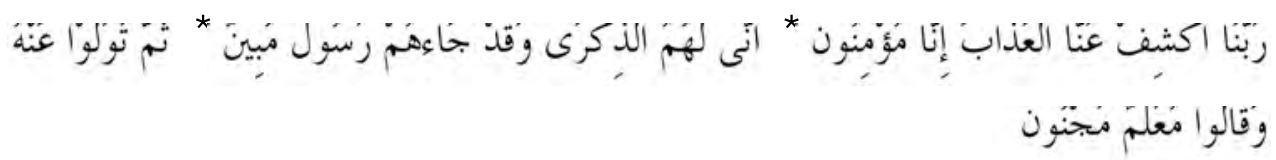

"(mereka berdoa): "Ya Tuhan Kami, lenyapkanlah dari Kami azab itu. Sesungguhnya Kami akan beriman”. Bagaimanakah mereka dapat menerima peringatan, Padahal telah datang kepada mereka seorang Rasul yang memberi penjelasan. Kemudian mereka berpaling daripadanya dan berkata: "Dia adalah seorang yang menerima ajaran (dari orang lain) lagi pula seorang yang gila." (Q.S. ad-Dukhaan: 12-14).

Dalam satu riwayat dijelaskan bahwa pada suatu hari telah datang seseorang kepada Ibn Mas'ud dan mengatakan kepadanya: “Aku meninggalkan masjid sedangkan di sana ada seorang yang menafsirkan Al-Qur'an menurut pikirannya sendiri. Ia menafsirkan firman Allah dalam surat Ad-Dukhaan ayat 10 dengan mengatakan bahwa pada hari kiamat nanti akan datang kepada manusia kabut yang menyesakkan pernafasan mereka, sehingga mereka terkena semacam flu. Ibn Mas'ud berkata: "Barangsiapa mengetahui sesuatu, maka hendaklah ia berkata berdasarkan ilmunya, dan barang siapa tidak mengetahui ${ }^{15}$ sesuatu, hendaklah ia berkata: Allah yang lebih mengetahui".

Munculnya kata kabut dalam surat ad-Dukhaan ayat 10-11 di atas, menurut Syaltut adalah dikarenakan kaum Quraisy menentang Nabi Muhammad SAW, sehingga beliau berdoa agar diturunkan pada mereka musim kemarau sebagaimana yang pernah menimpa kaum yang durhaka kepada Nabi Yusuf a.s. Maka terjadilah bencana kelaparan dan kesusahan yang membuat kaum Quraisy sangat menderita, sampai memakan tulang-tulang. Setiap orang lalu menolak ke langit dan yang nampak dalam penglihatannya adalah kabut. ${ }^{16}$

Syaltut juga mengemukakan contoh penafsiran dengan menggunakan pendekatan ilmiah (tafsîr bi al-ilmi), di mana menjadikan benda-benda hasil temuan ilmu pengetahuan modern sebagai bahan interpretasi terhadap sesuatu yang gaib. Misalnya, kata-kata al-Kitâb al-Mubîn dan al-Imâm al-Mubîn ditafsîr kan sebagai pencatatan elektronik untuk perekaman suara. Alat-alat tersebut memang dapat dipergunakan untuk merekam suara, akan tetapi menurut mereka tidak mustahil orang akan dapat menggunakan perekaman untuk keperluan mencatat segala gerak-

15 Ibid, hal. 15.

16 Ibid. 
gerik lintasan hati. Padahal kedua ayat tersebut menurut Syaltut adalah memuat catatan segala kebaikan dan keburukan yang akan dihadapkan kepada setiap manusia pada hari kiamat.

Dari beberapa penafsiran yang dikemukakan oleh para mufasir di atas, akhirnya Syaltut sampai pada satu kesimpulan bahwa penafsiran mereka merupakan penafsiran yang terlalu dipaksakan dengan jalan mentakwilkan Al-Qur'an yang bertentangan dengan i'jâz. Al-Qur'ân. Padahal Tuhan tidak menurunkan Al-Qur'an sebagai kitab yang secara spesifik menerangkan teori-teori ilmiah, problem-problem seni serta berbagai macam pengetahuan. Dalam konteks ini, menurut Syaltut cukuplah kita meyakini bahwa Al-Qur'an tidak bertentangan dengan kebenaran apapun, termasuk kebenaran-kebenaran ilmiah yang dapat diterima oleh logika yang sehat.

Dengan demikian, korelasi antara ilmu pengetahuan dan Al-Qur'an bukanlah terletak pada kecocokan ayat-ayat Al-Qur'an dengan ilmu pengetahuan, melainkan terletak pada kondisi yang diberikan Al-Qur'an dalam pengembangan ilmu pengetahuan.

\section{F. Penutup}

Dari deskripsi, pembahasan dan analisis yang telah diuraikan di muka, dapat dikemukakan kesimpulan sebagai berikut:

Pertama, kontroversi para mufasir di seputar tafsîr bi al-ilmi muncul dikarenakan adanya keinginan dari masing-masing mufasir untuk menunjukkan adanya korelasi antara ilmu pengetahuan dan Al-Qur'an sebagai kitab suci yang berlaku sepanjang masa. Bagi para mufasir yang secara substansial menerima kehadiran tafsîr bi alilmi menjadikan ilmu pengetahuan sebagai referensi untuk menafsirkan Al-Qur'an. Sikap semacam ini ditunjukkan oleh al-Sayuti yang mewakili kelompok mutaqaddimin dan kemudian diikuti oleh Tantawi Jauhari dari kelompok muta'akbkhirin. Al-Sayuti di dalam penafsirannya cenderung menyeimbangkan

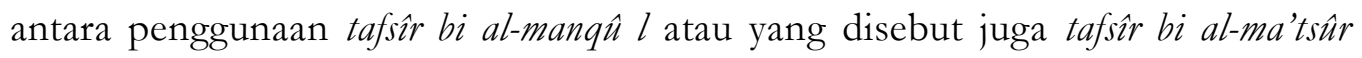
(penafsiran yang menggunakan nash-nash Al-Qur'an, hadis dan atau perkataan para sahabat-sahabat dan tabi'in) dan tafsîr bi al-ma'qûl atau yang disebut juga tafsîr bi al-ra'yi (penafsiran yang didasarkan pada ijtihad dan menjadikan akal sebagai pendekatan utama).

Sementara Tantawi Jauhari tampaknya tidak terlalu terikat dengan tafsîr bi almanqûl. Ia lebih cenderung mengedepankan logika dan menyelaraskan penafsirannya 
dengan perkembangan ilmu pengetahuan. Sedangkan Mahmud Syaltut menolak kehadiran tafsîr bi al-ilmi. Ia menekankan bahwa korelasi antara Al-Qur'an dan ilmu pengetahuan terletak pada spirit yang diberikan Al-Qur'an terhadap pengembangan ilmu pengetahuan. Al-Qur'an pada dasarnya tidak pernah bertentangan dengan kebenaran apapun, termasuk kebenaran ilmiah yang dihasilkan oleh ilmu pengetahuan.

Kedua, isyarat-isyarat Al-Qur'an tentang fakta ilmiah yang disinyalir di dalam ayat-ayat kauniyah sesungguhnya tidak dimaksudkan untuk konsumsi penerapan sains modern, tetapi ada misi penting yang harus menjadi titik perhatian umat manusia, yaitu untuk bahan kajian dan pemikiran, sehingga pada akhirnya akan memperkuat keyakinan tentang kebenaran adanya Allah SWT Yang Maha Pencipta. Sains modern yang benar dan mapan dapat dijadikan sarana untuk memahami keagungan Allah yang diperlihatkan melalui ayat-ayat-Nya.

\section{DAFTAR PUSTAKA}

Ahmad, Hanafi. T.t. al-Tafsîr al-Ilmi li al-Ayât al-Kauniyah. Makkah: Dar al-Ma'arif. Al-Aqqad, Abbas Mahmud. 1974. al-Falsafah Al-Qur'aniyah. Bairut: Dar al-Kitab alLublani.

Amal, Taufik Adnan, dan Pengabean, Syamsu Rizal. 1990. Tafsir Konstektual AlQur'an, Bandung: Mizan.

Amal, Taufik Andan. 1992. "Pembaruan Penafsiran Al-Qur'an di Indo-Pakistan" dalam Ulumul Qur'an, Vol. III.

Baljon, J.M.S. 1991. Tafsir Qur'an Muslim Modern, alih bahasa Muiz, A. Ni'amullah. Jakarta: Pustaka Firdaus.

Bucaille, Maurice. 1979. Bible, Qur'an, dan Sains Modern, alih bahasa Rasyidi. Jakarta: Bulan Bintang.

Fauzi, Ihsan Ali. 1990. "Kaum Muslimin dan Tafsîr Al-Qur'an” dalam Ulumul Qur'an. Vol. II.

Jauhari, Tantawi. T.t. al-Jawâhir fî Tafsîr Al-Qur'ân. Beirut: Dar Ma'arif.

Munawwir, Ahmad Warson. 1999. al-Munawnir Kamus Arab-Indonesia. Yogyakarta: Pustaka Progressif. 
Al-Rahman, Fahd, Abd. 1986. Ittijahât al-Tafsîr fî Al-Qur'ân al-Rabi 'Asyar. Mamlakah al-Arabiyah al-Sa'udiyah.

Shihab, Quraish, M. 1992. Membumikan Al-Qur'an, Bandung: Mizan.

Al-Suyuti, Jalaluddin. T.t. al-Itqân fî̀ Ulùm Al-Qur'ân, Juz. II, Beirut: Dar al-Fikr.

Syaltut, Mahmud. 1974. Tafsîr Al-Qur'ân al-Karîm al-Ajza al-Asyar al-Ulâ. Beirut: Dar al-Syuruq. 